\title{
Sosyal Hizmet Bağlamında Aliya İzzetbegoviç’in Düşünce Dünyası
}

\author{
The World of Thought of Aliya Izetbegovic in the Context of Social Work
}

\author{
Harun Ceylan* - Metin Zafer**
}

\begin{abstract}
The idea of a social state that protects the individual and society began to develop and was institutionalized as a result of the economic and social crises arising from wars, famines, and epidemics during the twentieth century, especially in Europe. With the erosion over time of natural networks such as family and kinship that provided social security and social services to the individual in the past, the state gradually assumed this role. The rights of disadvantaged groups such as women, minorities, immigrants, unemployed people, elderly people, and children were reorganized within the framework of fundamental rights such as equality, justice, democracy, and freedom as a requirement for the emerging understanding of the social state and gained universal recognition. As a thinker who witnessed the wars and socioeconomic and political crises in Europe during that period, the works of Alija Izetbegovic are shaped by fundamental universal social rights, democracy, equality, and morality and deal with topics such as family, women, elderly people, children, poverty, war, crime, and so on. As the founding head of state of the Republic of Bosnia and Herzegovina, the works of Alija Izetbegovic are mainly analyzed through the lenses of political philosophy, religion, and morality. However, many of Aliya's ideas about social services fall in line with the present-day human rights discourse. This study will seek to answer the question of what the social work paradigm is in Aliya Izetbegovic's works by discussing the ideas expressed by the thinker within the scope of social services issues. Accordingly, Aliya's works were analyzed through social services-themed topics such as the issues of family, women, crime, and elderly people, revealing universal discourses that can go beyond political and religious perceptions of Aliya's works.
\end{abstract}

Structured Abstract: The Global Economic Depression in 1929 and the First and Second World Wars that followed gave way to the implementation of new political systems and economic models in many regions of the world and, specifically, in Europe. With the end of the Second World War, the Euro-centered welfare state began to be institutionalized, and this period was described as a "golden age." During this period, the state stood out as the main element protecting the individual and society against social and economic risks. In this context, the state developed policies based on equality, justice, democracy, freedom, and human rights more

\footnotetext{
* Doç.Dr., Yalova Üniversitesi, İnsan ve Toplum Bilimleri Fakültesi, Sosyal Hizmet Bölümü Assoc. Prof. Dr. Yalova University, Humanities and Social Sciences Faculty, Department of Social Work ORCID 0000-0001-9047-2316 hrceylan@gmail.com

*** Doktora Öğrencisi, Yalova Üniversitesi, Sosyal Bilimler Enstitüsü, Sosyal Hizmet Bölümü

Ph.d Student, Yalova University, Graduate School of Social Sciences, Department of Social Work ORCID 0000-0002-2360-1162 metinzafer2344@gmail.com

Cite as/ Atıf: Ceylan, H. \& Zafer, M. (2020). Sosyal hizmet bağlamında Aliya İzzetbegoviç'in düşünce dünyası. Turkish Studies, 15(5), 2253-2265. https://dx.doi.org/10.7827/TurkishStudies.44806

Received/Geliş: 02 July/Temmuz 2020

Accepted/Kabul: 25 August/Ağustos 2020

Copyright $($ C MDE, Turkey
} 
than ever before. Social policies and social services were developed for many disadvantaged groups such as children, seniors, immigrants, and the unemployed.

Europe's transformation was surprisingly fast although it was a field of wars and devastation till recently. This state of prosperity began to develop since 1945 and has been increasingly institutionalized. Between 1945 and the early 1970s, human-centered policies were implemented. However, since the second half of the 1970s, political and economic developments interrupted this process, and liberal policies began to be adopted again. Instead of human-centered policies, policies centered on the economy became dominant. A number of social and political developments led to the emergence of conflict, crises, and social problems again in Europe.

With the separation of the Eastern Bloc countries, increasing tensions and conflicts led to the questioning of not only the understanding of the European welfare state but also basic European ideals such as democracy, freedom, and justice. During this period, human rights violations, war crimes, and conflicts that could be defined as genocide, especially in Bosnia and Herzegovina, shocked the world and Europe.

What is surprising is the human-centered thinking system that developed in light of the principles of equality, justice, democracy, and freedom that were considered to be the fundamental principles of European enlightenment by Alija Izetbegovic, a thinker at the heart of all these conflicts and human rights violations.

As the founding head of state of the Republic of Bosnia and Herzegovina, the works of Alija Izetbegovic are mainly analyzed through the lens of political philosophy, religion, and morality. However, many of Aliya's ideas about social services fall in line with the perspective of social services and human rights that exist today. This study seeks to understand what the social work paradigm is in Aliya Izetbegovic's works by discussing the ideas expressed by the thinker within the scope of social services issues. Accordingly, Aliya's works were analyzed through social services-themed issues of family, women, crime, and elderly people, revealing universal discourses that can go beyond the political and religious perception of Aliya's works.

In this context, groups such as families, elderly people, women, young people, children, criminals, disabled people, and persons with substance use issues that fall in the realm of social services are addressed in a structure formed by universal values such as freedom, equality, democracy, and human rights in Aliya's works. Aliya stands out as a social scientist working on many personal and societal issues including the protection of the institution of family, the minimization of divorce rates, and the prevention of abuse, women's equality, women's rights, feminist movements, alcoholism, and suicide.

Intersecting points related to social services areas in the ideology of Aliya can be expressed as follows: Social work does not sacrifice the individual for the sake of society, and the individual is at the heart of Alija Izetbegovic's ideas. Only a society woven with a moral system built by individuals who have created their personalities with free will can reproduce a moral individual. In this respect, just as people form the core of social service activities, the individual is at the center of Aliya's ideas.

Aliyaizetbegovic's philosophy was evaluated in the context of the contemporary discourse of social work. The present study found that Aliya's individual and social analyses were in harmony with the areas and the perspective of social services.

Aliya emphasized that the institution of family has been weakened in modern societies, women's labor is used as cheap labor, and women's economic value in the house is not recognized, and children and elderly people face several challenges.

Furthermore, Aliya's ideology underlined that concepts such as human rights, social justice, freedom, and equality in regards to the global social services are universal by nature and they should not be ignored. The need for all these values is often highlighted in Aliya's thought and was analyzed thoroughly in the context of global social work, crimes against humanity, racism, genocide, and war.

Given the period and place in which he lived, it was a time when differences were not welcome, "the other" had no right to live, free thought had no space, justice was on hold, and all kinds of human rights violations took place. Despite all these unfavorable conditions, the fact that the human individual was at the heart of Aliya's struggle and ideas is quite important because it shows that he did not stop believing in freedom, equality, democracy, morality, and human rights. This conclusion means that Aliya's ideas should be taken 
into account in addressing today's social problems and issues in social services areas in terms of universal values.

The works of Alija Izetbegovic are based on a humanistic system of thought, consisting of a synthesis of the modern Western and traditional Eastern ideologies. They address several issues discussed in the scope of modern social services areas. In this regard, it appears to be necessary to reevaluate Alija Izetbegovic's works in the context of political and religious philosophy and also from the perspective of social services and sociology.

Keywords: Social Work, Alija Izetbegovic, Human Rights, Democracy, Freedom

Öz: Yirminci yüzyıl boyunca özellikle Avrupa'da yaşanan savaş, kıtllk ve salgın hastalıklarla birlikte ortaya çıkan ekonomik ve sosyal krizler neticesinde bireyi ve toplumu güvence altına alan bir sosyal devlet anlayışı gelişerek kurumsallaşmaya başlamıştır. Geçmiş dönemde birey için sosyal koruma sağlayan aile ve akrabalık gibi sosyal güvenlik ve sosyal hizmet sunan doğal ağlar giderek erozyona uğradığından bu rolü üstlenen asli unsur devlet olmuştur. Gelişen sosyal devlet anlayışının bir gereği olarak kadınlar, azınlıklar, göçmenler, işsizler, yaşlılar ve çocuklar gibi dezavantajlı grupların hakları eşitlik, adalet, demokrasi ve özgürlük gibi temel haklar çerçevesinde yeniden düzenlenmiş ve evrensel bir boyut kazanmıştır. Aynı dönemde Avrupa'da yaşanan bütün savaşlara, sosyoekonomik ve siyasal krizlere tanıklık etmiş bir düşünür olarak Aliya İzzetbegoviç'in çalışmalarının da temel evrensel sosyal haklar, demokrasi, eşitlik ve ahlak temelinde şekillendiği ve sosyal hizmet alanları olarak ifade edilen aile, kadın, yaşlı, çocuk, yoksulluk, savaş, suç gibi konuları kapsadığı görülmektedir. Ancak Bosna Hersek Cumhuriyeti'nin kurucu devlet başkanı olması sebebiyle Aliya İzzetbegoviç̧'in eserleri daha çok siyaset felsefesi, din ve ahlak yaklaşımları üzerinden ele alınmıştır. Oysa Aliya'nın sosyal alana dair söylediği fikirlerin pek çoğu bugün var olan sosyal hizmet ve insan hakları perspektifine uygun düşmektedir. Bu yönüyle bu çalışmada düşünürün sosyal hizmet konuları kapsamında ifade ettiği fikirlere yer verilerek Aliya İzzetbegoviç düşüncesinde sosyal hizmet paradigmasının ne olduğu sorusuna cevap aranmıştır. Buna göre Aliya'nın eserleri aile, kadın, suç, yaşlı gibi sosyal hizmet temalı konu başlıkları üzerinden analiz edilmiş ve Aliya'nın eserlerine dair siyasi ve dini algının ötesine geçebilen evrensel söylemleri açığa çıkarılmıştır.

Anahtar kelimeler: Sosyal Hizmet, Aliya İzzetbegoviç, İnsan Hakları, Demokrasi, Özgürlük

\section{Giriş}

1929 Dünya Ekonomik Buhranı ve sonrasında yaşanan Birinci ve İkinci Dünya Savaşları insanlar için koruyucu sosyal güvenlik sistemlerinin ve sosyal politikaların evrensel bir ihtiyaç olduğunun anlaşılması bakımından oldukça önemli dönüm noktaları olmuştur. Özellikle İkinci Dünya Savaşı'nın daha ağır yıkıcı sonuçları göstermiştir ki savaş öncesinin zengin, sağlıklı ve huzur içinde yaşayan kesimleri savaşla birlikte açlık, yoksulluk, hastalık, sakatlık, evsizlik, işsizlik gibi pek çok risk ve sorunla karşı karşıya kalmıştır. Yaşanan bu süreç ve sonrasındaki sosyoekonomik ve siyasal çalkantı dönemi toplumun tüm kesimlerinin günün birinde sosyal devletin sosyal güvenlik ve sosyal hizmet şemsiyesine ihtiyaç duyabileceğine dair fikir birliğine varmalarını beraberinde getirmiştir.

Özellikle 1945-1975 yılları arasında Avrupa ve Amerika kıtasındaki gelişmiş ülkeler başta olmak üzere pek çok ülkede yaşanan kültürel, siyasal ve ekonomik gelişmeler neticesinde bir "altın çağ” yaşanmaya başlamış ve bu süreç dünyanın diğer bölgelerine de giderek yayılmaya başlamıştır (Özdemir, 2005: 154). Ancak bu süreç 1970'li yılların sonlarına doğru artan ekonomik ve demografik krizlerle birlikte ortaya çıkan yaşlanma, işsizlik, sosyal dışlanma ve tek ebeveynli ailelerin artması gibi nedenlerle birlikte zayıflamaya başlamış ve altın çağını yaşayan refah devleti Batı Avrupa'da gerilemeye başlamıştır (Gökbayrak, 2009: 57).

Refah devletinin gelişme ve gerileme süreçlerinde sunulan sosyal hizmetler ve sosyal güvenlik sisteminin kapsamı kadar, bu hizmetlerin sunumunda ve finansmanında asıl aktörün devlet 
mi yoksa piyasa ya da aile, sivil toplum kuruluşları gibi sivil sektörlerin mi yer alacağıyla ilgilidir. Ancak Avrupa aydınlanma süreciyle ve Fransız İhtilaliyle birlikte benimsenen demokrasi, eşitlik, özgürlük, adalet gibi evrensel ilkelerin benimsenmesi konusunda en azından teorik düzeyde bir gerilemenin olmadığı söylenebilir. Ancak uygulamaya bakıldığında Avrupa'nın göbeği diye tabir edilen bir coğrafyada, eski Yugoslavya Cumhuriyeti'nin dağılmasıyla birlikte Bosna Hersek'te “Avrupa Değerlerinin" ve insan haklarının hiçe sayıldığı, soykırım boyutuna ulaşan savaş ve insani suçların işlendiği görülmüştür.

İşte tam da bu coğrafyada yaşanan bütün trajediye rağmen, hem Avrupalı hem de Müslüman bir aydın olarak Aliya İzzetbegoviç'in fikir ve uygulamaları dikkat çekici hale gelmektedir. Zira 1920'li yıllardan itibaren Avrupa tarihini oluşturan bütün önemli olayların canlı tanığı ve mağduru olan bir insan olarak Aliya'nın tutumu daha da anlamlı hale gelmektedir.

Çağdaş bir Avrupalı Müslüman düşünür olarak Aliya İzzetbegoviç hem dini metinleri hem de Avrupa Felsefinin temel eserlerini kendine has özgün bir üslupla ve eleştirel bir yaklaşımla analiz ederek sistematik bir düşünce geliştirmeyi başarmış, Hegel, Freud, Heideger, Tolstoy, Kundera, Hesse ve Marx'ın eserlerini incelemiş ve Bergson, Spengler, Kant'ın düşüncelerinden etkilenmiştir (Akın ve Karaarslan, 2016: 42-43).

Aliya'nın fikirlerini değerli kılan unsurlardan birisi de yaşadığı kötülüklere rağmen iyiye olan inancını ve tarafsızlığını kaybetmemiş olmasıdır. Modern refah devletinin sosyal risklere karşı koruma kalkanı oluşturduğu insanı toplumun çıkarlanı için ikinci plana atmasını eleştirerek gerçek anlamda bütün iyi ve güzel olanın özne olan ve özgür iradesiyle inşa ettiği ahlakıyla topluma değer katan insanı merkeze alması modern sosyal hizmet uygulamasıla kesişen temel noktasını oluşturmaktadır.

Zira "sosyal hizmetlerin, tipik özelliği, aileden topluluk ve devlete kadar uzanan bir grubun mensupları olarak bireylerle ilgilenmesidir. Sosyal hizmetler, ülkenin genel koşullan çerçevesinde bireylerin insana yaraşır bir biçimde varlıklarını sürdürebilecekleri ve ait oldukları grup ve toplumun bir üyesi olarak üzerlerine düşen görevleri yerine getirebilecekleri” (Dilik, 1980: 73) bir dünya inşa etmeyi amaçlamaktadır. Aliya'nın düşüncesinin merkezinde de özgür tercihleriyle ve ahlakıyla var olan insan vardır.

Hem bir sanat hem de bir bilim olarak tanımlanan sosyal hizmet bütün insanların yaşam kalitesini artırmak için toplum tarafından uygun görülen hizmetlerin sunulduğu, insanın yakın ve uzak çevresiyle bir bütün halinde etkileşim içinde olmalarını temin etmeye çalışan bir meslek ve bilim dalı olarak değerlendirilmektedir (Duyan, 2003: 1).

Tam da bu noktada bu çalışmada Aliyaİzzetbegoviç'in düşünce dünyasında modern sosyal devlet/refah devleti paradigmasıyla ve sosyal hizmet alanlarıyla örtüşen düşüncelerinin neler olduğu sorusuna cevap aranmaktadır. Temel insan hakları, özgürlük, demokrasi gibi evrensel değerler ve ilkelerle aile, kadın, çocuk, yaşlı, yoksul, savaş mağduru gibi dezavantajlılık ve sosyal hizmet alanları kapsamında ele alınan konu başlıkları üzerinden Aliya İzzetbegoviç’in eserleri tahlil edilerek bu alandaki fikirlerinin daha görünür hale getirilmesi amaçlanmaktadır. Böylelikle ahlak ve özgürlük üzerine inşa edilen Aliya düşüncesinin bireyin içine düştüğü sosyoekonomik ve politik açmazlara ürettiği çözüm daha görünür hale gelebilir.

Ayrıca "sosyal hizmet alanları" gibi somut bir kavramsallaştırma üzerinden yapılan bir analizle sadece Aliya'yı daha önce ele alınmamış bir yönüyle çalışılmış olmayacak aynı zamanda Aliya İzzetbegoviç'in düşünce dünyası daha yalın ve sade haliyle de sunulmuş olacaktır. Zira Türkiye'de Aliya İzzetbegoviç hakkında hazırlanan on yedi adet lisansüstü tezden sadece bir tanesi doktora tezidir ve bu tezlerin büyük bir bölümü din ve felsefe alanında yapılmış çalışmalardır.

Aliya'nın entelektüel kimliği üzerine yapılan birkaç akademik çalışmadan birisi olan Karaarslan (2010), Özdemir (2014) ve Akçay'ın (2016) çalışmaları Aliya İzzetbegoviç'in düşünce 
dünyasını ele alan çalışmalar olması bakımından önemlidir. Yine Özcan (2017)'ın çalışması da Aliya hakkında hazırlanmış tek doktora tezi olması bakımından dikkate değer bir çalışmadır.

Yine Aydın (2013), İslam (2013), Akın ve Karaarslan (2016), Karaarslan (2012; 2014) ve Özyurt (2016)'un çalışmaları da İzzetbegoviç'in düşüncelerinin anlaşılmasında derinlikli birer analiz geliştirmeleri açısından önemlidir. Ancak yapılan çalışmalar daha siyaset, ahlak felsefesi ve din üzerine yapılmış araştırmalardır. Bizim araştırmamızı diğerlerinden ayıran en temel unsur da burasıdır. Bu çalışma belirli alanlar ve konu başlıkları üzerinden Aliya İzzetbegoviç'in modern refah devleti ve sosyal hizmet söylemiyle örtüşen, çatışan veya bu söylemi aşan ifadelerinin ortaya çıkarılmasına ve daha iyi anlaşılmasına katkıda bulunmayı amaçlamaktadır.

$\mathrm{Bu}$ yönüyle de diğerlerinden ayrışan bu çalışmaya yönelik Aliyaİzzetbegoviç'in geniş ve derinlikli ahlak ve özgürlük anlayışı ekseninden uzaklaşarak onun fikirlerini daha yüzeysel ve sığ bir alana taşımak gibi eleştiri getirilebilir. Ancak tam tersine çalışmanın amacı Aliya'nın eserlerinin daha geniş bir alanda ve daha derinlikli analiz edilmesine katkıda bulunmaktır.

\section{Aliya İzzetbegoviç: Hayatı ve Düşünce Dünyası}

Belgrat'dan Bosanski Samac'a göç etmiş köklü bir ailenin çocuğu olarak 1925 yılında dünyaya gelen İzzetbegoviç'in adını aldığı dedesi Bosanski Samac'ın belediye başkanıydı. Babannesi İstanbul'dan Sıdıka Hanım, babası Mustafa bey, annesi ise Hiba hanımdır. Aliya İzzetbegoviç henüz iki yaşındayken ticaretle uğraşan babası Mustafa beyin kararıyla ailesiyle birlikte Saraybosyna'ya taşınmıştır. Bu tarihten sonra Aliya İzzetbegoviç'in bütün hayatı Saraybosna'da geçmiştir (Hacımeyliç, 2013: 15-16).

Saray Bosna'da Alman Lisesinde öğrenim gören Aliya İzzetbegoviç özellikle Alman felsefesi ve batı düşüncesinden etkilenmiştir. İzzetbegoviç almış olduğu eğitim ve araştırmacı kişiliğiyle özellikle Hegel, Freud, Heideger, Tolstoy, Kundera, Hesse ve Marx'ın eserlerini incelemiş ve Bergson, Spengler ve Kant'nn düşüncelerinden etkilenmiştir (Akın ve Karaarslan, 2016: 43).

Gençlik yıllarında aktif bir şekilde fikir ve eylem hayatı içinde yer alan İzzetbegoviç 16 yaşındayken Mladi Müslümani (Genç Müslümanlar) derneğine katılmış ve bu gerekçe ile üç yıl hapis yatmıştır. Yine 1983 yılında yargılandığ 1 Saray Bosna davasından da yaklaşık altı yıl cezaevinde kalmıştır. Hapishane hayatından sonra Doğu ve Batı Arasında İslam kitabı ile Özgürlüğe Kaçışım Zindandan Notlar eserlerini kaleme almıștır. Bu iki temel eseri İzzetbegoviç'in hayata, insana ve topluma dair temel fikirlerini ortaya koyması bakımından oldukça önemlidir. (Akın ve Karaaslan, 2016: 44).

Fikir hayatı kadar zengin bir eylem hayatı olan Aliya İzzetbegoviç Yugoslavya'nın dağılma süreciyle birlikte Bosna halkının kimlik kazanma ve uluslaşma sürecinde aktif olarak yer almış ve Bosna Hersek Cumhuriyeti'nin ilk Cumhurbaşkanı olarak bu görevini 1990 yılından 2000 yılına kadar sürdürmüştür. Sağllk gerekçeleriyle istifa ettiği 2000 yılından üç yıl sonra 2003 y1lında vefat etmiştir.

Hem batı hem de doğu dünyasının düşünce ve kültürüne vakıf bir "Avrupalı Müslüman düşünür olarak" Aliya İzzetbegoviç düşünce dünyasının merkezine "ahlak"1 koymuş, gerçek anlamda bir ahlaktan bahsedebilmenin de ancak "özgürlük"le mümkün olabileceğini ifade etmiştir. Bu yönüyle her şeyden önce Aliya bir "ahlak ve özgürlük” düşünürüdür (Akın ve Karaarslan, 2016: 42; Karaarslan, 2012: 111-114).

\section{Aliya'da Ahlak ve Özgürlük Temelinde İnsan Hakları ve Adalet}

Aliya'nın insan haklarına, adalete, demokrasiye ve eşitliğe olan bağlılığı hem fikri zeminde hem de pratikte kendini ispatlamıştır. Zira İzzetbegoviç düşünce dünyasını şekillendirmede hareket noktası olarak ahlakı seçmiştir. Bu nedenle Aliya'ya öncelikle bir ahlak düşünürü demek doğru olacaktır (Karaarslan, 2012: 112).Sosyal hizmetin kabul görmüş tanımı içinde Aliya'nın dünya 
görüşü ve pratikteki uygulamaları arasında bir bütünlük olduğu göze çarpmaktadır. Sosyal adalet, insan hakları, ortak sorumluluk ve farklılıklara saygı sosyal hizmet için teme konular arasında yer almaktadır (www. hacettepe.edu.tr, 2014).

Bu bağlamda insan onuruna uygun bir yaşamı engellediği için diktatörlüklere karşı çıkarken demokrasinin önemine vurgu yapmış ve demokrasi ile diktatörlük arasında net bir ayrım yapmıştır. Aliya'ya göre "diktatörlük günahı yasaklasa bile ahlaksızdır, demokrasi ona, izin verse bile ahlaklıdır.” (İzzetbegoviç, 2011a: 78).

Her ne kadar bir takım sosyal ve ekonomik haklar sunuyor olsalar da insan onurunu aşağılayan ve üretkenliği yok eden diktatör rejimler en nihayetinde insan ve toplum için olumsuz sonuçlar doğurmaktadır. Zira bu rejimlerde üretken, yetenekli ve farklı düşünen bireyler tasfiye edilmekte ve vasat bir sistem ortaya çıkmaktadır. (İzzetbegoviç, 2003: 546).

Aliya insanların eşit ve özgür yaratıldıklarına vurgu yaparak herhangi bir ırkın diğerinden üstün olmadığını ve herhangi bir milletin diğerinden iyi ya da kötü olmadığını, insanların doğuştan devredilemez haklara sahip olduğundan söz ederek, hiçbir otoritenin insanları bu haklardan mahrum etme hakkının olmadığını belirtmiştir. Aynı şekilde çoğunluğun tahakkümünden oluşan despotizme de karşı çıkan Aliya demokrasi ve özgürlüğün göstergesinin azınlıklara nasıl davranıldığıyla anlaşlabileceğini söylemektedir (İzzetbegoviç, 2003: 545). Tam da bu gerekçeyle kendi kurduğu Bosna Cumhuriyeti'nin demokratik bir cumhuriyet olmasını kaçınılmaz ön şart olarak görmüş, toplumun siyasal, ekonomik ve toplumsal dönüşümünün demokratik yöntem ve araçlarla mümkün olacağını ifade etmiştir (İzzetbegoviç, 2011b: 61, 2007b: 224). Zira "tarihi insanoğlunun sınav1 olarak gören İzzetbegoviç medeniyet sınavımızı verebilmemiz için, ahlakı ve ahlakın kökten bağımlı olduğu hürriyet fikrini savunmamı" gerektiğini söylemektedir (Karaarslan, 2013: 32).

Aliya'daki adalet kavramının da bütün evrensel adalet sitemine son derece entegre olduğu göze çarpmaktadır. Savaş sonrası dönemde Bosnalı bir takım askerlerin bazı Sırplar tarafından yapılan uygulamalara misillemede bulunma isteği karşısında "Sırplar bizim öğretmenimiz değil" diyerek, adalet ve insan hakları konusunda profesyonel bir tutum sergilemiş ve insanlara karşı tutumlarında onların dini ya da milli aidiyetlerine göre tutum sergilememiştir (Çil, 2018: 124, İzzetbegoviç, 2011a: 50).

Bu bağlamda hukuku güçsüzün hakkı olarak görür ve güçlünün hukuka ihtiyacı olmadığını belirtmiştir. Düşünce ve inanç özgürlügünün de farklılıklara saygının en temel insan hakkı olduğunu kurgulanmış hiçbir yapının ve dayatmaların insanları özgürleştiremeyeceğine ifade etmektedir. İdealize edilmiş bir dünyanın doğal gerçekliğe karşı bir telafi arayışı olduğunu belirterek, özgürlügün mizah üretmesi gibi totaliter rejimlerin de yalan ürettiğini söylemiştir. (İzzetbegoviç, 2019: 333, 2011b: 282).

Aliya insanların kardeş olduğunu ve eşit derecede haklarının olduğunu (İzzetbegoviç, 2007a: 53). sınıfsalanlayışın, adaletsiz, ahlaksız ve insani açıdan kabul edilemez bir sistem olduğunu vurgulamaktadır. "Gün içinde ekmeklerini nasıl kazandıklarına bakılmaksızın bütün iyi insanlar aynı topluluğa aittirler. Tıpkı çalışma faaliyeti içindeki pozisyonlarına ve siyasi tercihlerine bakılmaksızın tüm kötü ve ahlaksız insanların aynı sınıfa ait oldukları gibi.” (İzzetbegoviç, 2007a: 181).

\section{Bir Gerçeklik Olarak Savaş Suçu- Soykırım ve Irkçılık}

"Birleşmiş Milletler Genel Kurulunun 11 Aralık 1946 tarihli ve 96(I) sayılı kararında" soykırımın bir suç olarak belirlenmiş ve tarafların"Soykırım Suçunun Önlenmesi ve Cezalandırılması Sözleşmesi'nin hazırlamasına ilişkin düzenleme BM genel kurulu tarafindan 1948 yılında kabul edilmiştir. Buna göre ulusal, etnik, ırksal veya dinsel bir grubu, kısmen veya tamamen ortadan kaldırmak amacıyla işlenen fiillerden her hangi biri, soykırım olarak değerlendirilmiştir (www.ombudsman.gov.tr. Erişim Tarihi: 20.06.2020). 
İnsan hakları çerçevesinde bir suç olarak değerlendirilen soykırım uluslararası sosyal hizmet tarafından da insan değerinin yok sayılması olarak değerlendirilmekte ve bu yönüyle de sosyal hizmet alanının bir konusu olarak ele alınmaktadır (Ulutaş, 2015: 181).

Bununla beraber her ne kadar BM "soykırıma" karşı 1948 yılında böyle bir düzenleme yapmış olsa da Bosna'nın Müslüman halkının etnik temizlik, katliamlar ve nihai olarak soykırım yoluyla yok olma tehlikesiyle karşı karşıya kalmasında BM GK'nın silah ambargosu etkili olduğu ifade edilmektedir (Emgili, 2012: 65-66). BM'nin kararından yaklaşık 50 yıl sonra 1995 yılında Srebrenitsa' da 8372 sivilin katledilmesi Dünya Savaşlarından sonra yaşanan en büyük katliam olarak tarihe geçmiştir.

Ölenlerin sayısının tam olarak bilinmediği, cami, okul, kütüphane, üniversite binalarının yakılıp yıkıldığı bir ortamda "biz ne onları öldürmek istiyoruz ne de kiliselerini yıkmak istiyoruz" sözleri Aliya'nın savaş suçlarına ve soykırıma karşı tavrını göstermesi bakımından oldukça önemlidir (İzzetbegoviç, 2011b: 25).

Yine Aliya, yapılan soykırımlarda halkların bir suçunun bulunmadığını bu soykırımların birer entelektüel cinayet olduğunu, yalancı din mensupları tarafindan ikna edilen bir cinayet teorisinin söz konusu olduğunu ifade etmiştir (İzzetbegoviç, 2011b: 48-49).

Aliya 1993 yılında BM genel kurulunda yapmış olduğu konuşmasında yapılan soykırımın başlangıcının Londra konferansının olduğunu, işlenen insanlık suçunu genel kurulda şu şekilde ifade etmiştir: "Bu görülmemiş zulümle aynı zamanda ülkemiz üzerine siyasal vivisection (canlı kesim) deneyi uygulanmaya çalışılmıştır. Ancak maalesef bu deney çeşitli hipotezlerin denenmesi yoluyla bizim canlı halk ve hükümet bedenimiz üzerinde "in vivo"(canlı) icra edilmektedir." (İzzetbegoviç, 2007b: 91). Bu konuşmasıyla aslında yaşanan bu savaş suçlarının bir ırkçılık anlayışının sonucu olduğunu ortaya koymuştur. Bu yönüyle doğası gereği ortaya çıktığ1 ilk günden beri irkçılığın karşısında olan sosyal hizmetin odak noktası insan değeri üzerine konumlanmıştır. Bu yönüyle sosyal hizmet her koşulda bir insan hakkı olan ırkçıllk gibi uygulamaları reddeder ve çalışmalarını bu düzlemde şekillendirir (Tek, 2019: 1151).

Bu bağlamda AGİT zirvesinde, Budapește'de yapmıș olduğu konuşmasında ırkçıllığa karşı mücadelesini anlatan Aliya(İzzetbegoviç, 2011b: 192).Hegel'in bazı ırklar üzerine yapmış olduğu açıklamalarına karşı çıkarak bu durumu açık bir ırkçılık olarak nitelemiş, hiçbir ulusun ve ırkın topyekûn suçlanamayacağını belirtmiştir (İzzetbegoviç, 2011a: 1-2). Aynı şekilde ırkçılığın ilmi bir temelinin de bulunmadığını belirten Aliya, insan genlerinin \%99'unun tüm insanlarda ortak olduğunu \%1'in ırkı belirlediğini ifade etmiştir (İzzetbegoviç, 2011a: 101).

\section{Anne ve Kadın Üzerine Değerlendirme}

Aliya, tarihsel süreçte kendisini anne olarak değerlendiren kadının bu misyondan sıyrılarak bir şahsiyet olması gerektiğine yönelik feminist eleştiriye karşı çıkmaktadır. Feminist yorumda anne olmakla şahsiyet olmanın birbirinin karşısına konumlandırılmış olmasını feminist diyalektiğin bir hatası olarak değerlendirmiş ve kadına şahsiyet kazandıran en büyük erdemin annelik olduğunu vurgulamıştır (İzzetbegoviç, 2011a: 29)."Kadın sadece anne olarak yeri doldurulamaz ve mutlak değere sahiptir. Kadını anne olarak yıkan hiç kimse onun daha fazla saygı görmesine ve önemine katkıda bulunamaz, çünkü annelik hakkı sadece dokunulamaz değil, aynı zamanda insanlığın bildiği en eski haktır." (İzzetbegoviç, 2007a: 40).

Feminist harekete olduğu kadar İslam toplumlarındaki kadına bakışa da yoğun eleştiri getirmektedir. Eğitimsiz, mutsuz ve ihmal edilmiş bir annenin, Müslüman halkların neslinin başarılı olmasını sağlayacak oğul ve kızları yetiştiremeyeceğine ayrıca çok eşliliğe son verilmesi gerektiğine, yine kadına haksızlık yapmak adına hiç kimsenin İslam'a dayanma hakkının bulunmadığını belirterek kimsenin buna benzer suiistimal içinde bulunmaması gerektiğinin altını çizmiştir. Bu bağlamda erkek ve kadının eşdeğer olduğunu ayrıca boşanmanın azaltılması ve olası herhangi bir 
boşanma durumunda da kadın ve çocuğun maddi açıdan güvence altına alınması gerektiğini savunmuştur (İzzetbegoviç, 2007a: 189-190).

Kadın ve erkek arasında bir eşitlik tartışmasına girmenin de çok anlamlı olmadığını belirten Aliya'ya göre "üstün veya aşağı olma meselesi sadece aynı tür (çeşit)" için geçerlidir. Zira kadın ve erkek birbirinden farklıdır bu nedenle kadının mı yoksa erkeğin mi daha önemli olduğuna dair bir tartışma "kalp mi akciğer mi önemlidir" kadar tuhaf bir tartışmadır (İzzetbegoviç, 2007a: 37).

Aliya, kadın istihdamı konusunda da son derece ilginç tespitlerde bulunmuştur. Buna göre, dünya iş gücünün üçte birinin kadınlardan oluştuğunu buna mukabil toplam gelirin onda birini aldıklarını, biri işyeri diğeri ev olmak üzere iki iş günleri olduğunu ve eşlerine kıyasla yarı yarıya boş vakitlerinin olduğunu belirtmiştir (İzzetbegoviç, 2011a: 93). Bununla beraber "kadınların ev dışında istihdamı ve üretime katılması" konusunda artan bir baskının olduğunu ve "doğum yapmak, çocuk yetiştirmek ve aileye bakmak yoluyla kadının" ev içinde yapmış olduğu ekonomik değerin göz ard1 edildiğini ifade etmiştir (İzzetbegoviç, 2011a: 85). Gerçekten de günümüzde ev işlerini yapan, çocuklarına bakan kadınların ekonomik ve sosyal anlamda hiçbir güvencesinin olmaması bir çelişkidir. Ev içi emeğin değersiz olması yanında ev dışında da kadınlar ucuz işgücü olarak değerlendirilmekte ve daha çok düşük ücretli vasıfsız işlerde istihdam edilmektedirler.

Aliya bu durumu örnek üzerinden açıklığa kavuşturmuştur. Gelişmiş ve farklı sosyoekonomik modellere sahip ülkelerde kadınlara anne olup ta çocuk bakmanın gereksiz olduğunun her platformda tekrarlandığını, buna mukabil hekim, iş kadını, gazeteci olmalısın gibi telkinlerde bulunulduğunu, fakat bunun bir paradoks olduğunu ABD ve Rusya'da rakamların bunun tersini gösterdiğini belirtmektedir. Bu ülkelerde çalışan kadınların \%95'nin çiftlik ve fabrikalarda kötü koşullarda çalıştırıldığını yine ABD ve İngiltere'de siyasi arenada kadınların oranının sadece \%5 olduğunu söylemektedir (İzzetbegoviç, 2007a: 39-40). Özetle Aliya, modern toplumlarda kadının, ucuz iş gücü olarak kullanıldığını, kalifiye olan işlerde kadının daha az görünür olduğunun altını çizmiştir. Kadının evdeki iktisadi değerinin göz ardı edilmesinin sebebi ise artan sanayileşmeyle birlikte ucuz işgücüne duyulan talebin karşılanması adına kadınların ev dışı işlere yönlendirilmesidir(İzzetbegoviç, 2007a: 39). Bütün bu süreci meşrulaştırmanın yolu ise anneliğin aşağılanmasıyla olmuştur. "Medeniyet anneliği kölelik ilan etmiş ve kadına bundan kurtuluş vadetmiştir....ancak değer ve saygının hamili olabilecek yegâne şey olan şahsiyeti ondan koparmıştır." (İzzetbegoviç, 2019: 266).

Kapitalist toplumlarda kadın sadece ekonomi piyasasında bir işgücü olarak görüldüğü için çocuk doğuran ve büyüten anneler ekonomik anlamda bir "değer" olarak algılanmamış ve annelere "emeklilik" gibi sosyal bir hak verilmemiştir. Oysa anneler sadece toplumun kültürel gelişimine katkıda bulunmakla kalmazlar, aynı zamanda toplumsal işgücü, üretim ve tüketimi destekleyerek ekonominin geleceğini de teminat altına alırlar. Bununla beraber İzzetbegoviç kadınların eve kapatılarak toplumsal hayattan soyutlanmaması gerektiğini, İslam'ın genel ilkelerini dikkate alarak kadınların sanat ve iş yaşamında da yer alması gerektiğini vurgulamıştır (İzzetbegoviç, 2010'dan akt.,Toktaş, 2016: 31). En nihayetinde kadın ataerkil yapının geleneksel baskısından uzaklaşarak sosyal hayatta ve çocuk yetiştirmede ön planda olmalıdır. Zira toplumun ancak kadınlar eliyle ve annelik müessesiyle aydınlığa kavuşacağına yönelik genel bir konsensüs vardır (Akın ve Karaarslan, 2016: 51).

\section{Aile -Çocuk ve Yaşlı}

Aliya İzzetbegoviç'in ahlak ve özgürlük üzerine inşa edilen fikirlerinin yeşerdiği en önemli kurum ailedir. Zira aile bireyin şahsiyet kazandığ 1 kadın ve erkeğin anne ve baba olduğu aynı zamanda tüm toplumsal değerlerin yeniden üretildiği bir kurum olarak toplum açısından vazgeçilmezdir. Çocuk, yetişkin ve yaşlı için en önemli özgürlük mekânı olarak aile, ahlakın anlam kazandığı ve bireyin insana dönüştüğü kurumdur. 
Çocuğa, annesi ve ailesinin verebileceği sıcaklık ve şefkati hiçbir toplumun ve hiçbir devlet kurumunun veremeyeceğini belirten Aliya aile için alternatif olması istenen kurum ve modelleri de eleştirmiştir (İzzetbegoviç, 2007a: 42). Aynı şekilde Platon'un ütopya anlayışından hareketle en açık haliyle sosyalist rejimlerde görüldüğünü ifade ettiği ideal toplum arayışını da kreş, zorla terbiye, toplumsal eğitim gibi kademelerden geçerek aile, özgürlük ve sevginin bir romantizme dönüşmesinin nedeni olarak açıklamıştır (İzzetbegoviç, 2019: 262-263).

"Tüm dinler aileyi insanın yuvası, anneyi ilk ve yeri doldurulamaz bir eğitici olarak telakki eder ve yüceltir. Bunun tam aksine ütopyalar toplumsal eğitimden, kreş ve bakım evlerinden büyük bir heyecanla söz edeceklerdir. Bu kurumların isimleri ne olursa olsun, annenin olmaması ve çocukların paralı memurlara teslim edilmesi ortak noktalarıdır." (İzzetbegoviç, 2019: 262).

Aliya, Sovyet rejimi tarafindan aile karşıtı ütopik toplum oluşturmak için kurulan kreşleri birer fabrikaya benzeterek, insan yetiştirmenin bir modeli olarak bu durumu tavuk yetiştirme süreci olarak görür. Aliya, Marx’ın Kapital'deki "Her iki cinsiyetten çocukları ailelerden olduğu kadar hiç kimseden daha fazla korumak icap etmez" sözünü medeni toplumların aileye karşı olumsuz tutumunun zirvesi olarak değerlendirmiştir (İzzetbegoviç, 2019: 263).

Aliya yaşlıların toplum açısından önemli olduğunu toplumların dezavantajlı gruplara bakışının o toplumun aynası olacağını da şöyle belirtmiştir."Bir toplumun mihenk taşı, onun düşmanlarına, hastalara, muhtaçlara ve yaşlılara yönelik tavrıdır. Hiçbir hümanizmin bulunmadığ1 bir ütopyada bu insan tabakaları ölüme mahkûm edilir. Belki açıkça olmasa da zımnen. Onlar orada mevcut değildirler." (İzzetbegoviç, 2011a: 248).

Aliya yaşlılığın modern dünyada anlamının kaybolduğunu ayrıca dini ve ahlaki sorumluluklar yerine rasyonel bakışı temel alan medeniyetin, dünyayı her geçen gün gençlerin ölçü ve zevkleri doğrultusunda biçimlendirdiğini ve cinselliğe yüklenen değerin artması ile beraber gençliğin ön planda tutulduğu buna mukabil yaşlıların ise birer alay konusu olduğundan bahsetmiştir. (İzzetbegoviç, 2019: 262). Gerçekten de modernleşme süreciyle birlikte gençliğin kutsandiğı, yaşl11ığınsa istenmeyen bir olgu olarak görülmeye başlandığını söylemek mümkündür. Geleneksel toplumda bir "değer" olarak algılanan yaşlı ve yaşl1lık, modern dönemde bir sorun olarak görülmeye başlamıştır (Ceylan, 2020).

Son olarak Aliya, yaşlılar ve çocuklara ait kurumsal mekânlar için ise "kreşler ve huzur evleri suni doğumu ve suni ölümü çağrıştırmaktadır. İkisinin özelliği de konforun ön planda olması, sevgi ve sıcaklığın bertaraf edilmesidir" demektedir (İzzetbegoviç, 2019: 266). Her ne kadar modernleşme süreciyle birlikte yaşanan toplumsal değişmenin bir sonucu ve bir ihtiyaç olarak ortaya çıksalar ve varlıklarını sürdürseler de bu kurumların birey için aile ortamının sağladığı sevgi, güven ve şefkati sağlamak konusunda yeterli olduğunu söylemek kolay değildir. Ancak her şeye rağmen bu kurumların da toplumsal ihtiyaçların bir sonucu ortaya çıktığını da dikkate almakta yarar vardır.

\section{Suç- Madde Kullanımı-Yoksulluk-İntihar ve İstismara Dair Kısa Değerlendirme}

Cezalandırılmamış suçların dünyayı zehirlemeye devam edeceğini belirten İzzetbegoviç (2003: 394) suç ve ceza arasında caydırıcılığın önemine ve suça mağdur açısından yaklaşan Mağdurbilim (victimology)'in daha adil ve dengeli bir sistemin inşa edilmesine katkıda bulunabileceğine inanmaktadır. Zira özellikle Avrupa'da suçluların cezalandırılması ya da affedilmesi tartışmalarında mağdurlar dikkate alınmamaktadır. Suçları açıklayan ve suçluyu affeden bu yaklaşımın Darwinist bir temele dayandığını belirten Aliya'ya göre Darwin'in "insanın özgürlüğü yoktur ve insan şartların sonucu ve kurbanıdır" sözünün modern toplumlardaki suçluya bakış açısının zeminini oluşturmaktadır. Oysa suçluların affedilmesi masum bir insana ve potansiyel kurbana karşı bir zulümdür (İzzetbegoviç, 2011a: 165-196). 
İşlenen suçlarda alkol kullanımının da önemli bir faktör olduğundan hareketle sadece Sovyet Rusya'da 1960-80 yılları arasında alkol bir buçuk milyon insanın doğrudan ya da dolaylı yoldan öldüğünü, bunun Hiroşima' ya atılan 13 bombaya denk olduğunu ve yine bütün sağlık harcamalarının önemli bir bölümünün alkolizme bağlı hastalıkların tedavisinden kaynaklandığını belirtmiştir (İzzetbegoviç, 2011a: 86).

Aliya gelişmiş ülkelerdeki bilimsel araştırmaları, BM raporlarını ve kriminoloji kongrelerini referans göstererek suçun geçmişte alkolizm ve yoksullukla ilişkilendirildiğini şimdi ise hem suç oranlarındaki artış hem de madde kullanımının gelişmişlikle açıklandığını aynı şekilde ruhsal bozuklukların artışı ve bağlı olarak artan intiharların da artması karşısında medeniyetin çaresiz kaldığının altını çizmektedir. Bu durum karşısında Aliya suç, intihar, madde kullanımı ve ruhsal hastalıkları azaltmada dini, ahlaki eğitimi ve aileyi reçete olarak göstermektedir (İzzetbegoviç, 2019: 113-123).

İslam toplumlarında ise yaşanan yoksulluk ve gelir adaletsizliğinin pek çok diğer sorunun kaynağı olduğunu bu sorunların temelinde ise yardımlaşma eksikliği ve toprak reformunun olduğunu belirtmektedir (İzzetbegoviç, 2007a: 26).

\section{Sonuç}

Sosyal hizmet ya da diğer bir adıyla sosyal çalışmanın amacı genel anlamda, bireylerin ve de toplumların refahını, iyilik hallerini daha net ifade ile insan yaşamına dair her türlü iyi oluşa katk1 sağlamaktır. Ayrıca sosyal hizmet birey ve toplumun refahını, iyilik hallerini tehdit eden her türlü sosyal sorunu ortadan kaldırmayı ve/veya bireyi güçlendirerek bireyin sorunlarla baş etme kapasitesini artırmaya çalışan bir alandır.

Sosyal hizmet çocuk, genç, yaşlı, engelli, kadın, göçmen, suçlu, yoksul bütün risk ve dezavantajlarıyla birlikte insanı bir bütün olarak, kategorize etmeden ele alır. Başka bir deyişle sosyal hizmetin merkezinde insan vardır ve sosyal hizmet insanı ailesi, sosyal çevresi ve içinde bulunduğu toplum bağlamında değerlendirir.

Avrupa'lı bir siyasetçi ve düşünür olarak daha çok siyaset bilimi, ahlak ve din sosyolojisi alanındaki görüşleriyle ön plana çıkan Aliya İzzetbegoviç'in eserlerinin merkezinde de insanın olduğu ve insanın yüksek iyilik halinin nasıl mümkün olacağı sorusuna cevap arandığ1 görülmektedir.

Bu bağlamda Aliya'nın eserlerinde sosyal hizmetin temel çalışma alanları içinde yer alan aile, yaşl1, kadın, genç, çocuk, suçlu, engelli, bağımlı gibi gruplar genel çerçevesini özgürlük, eşitlik, demokrasi ve insan hakları gibi evrensel değerlerin oluşturduğu bir bütünlük içinde ele alınmaktadır. Bu yönüyle Aliya'nın ailenin korunması, boşanmanın azaltılması, istismarın önlenmesi, kadın erkek eşitliği, kadın hakları, feminist hareketler, alkolizm ve intihar gibi pek çok bireysel ve toplumsal konuyla ilgili çalışan bir sosyal bilimci olduğu görülmektedir.

Sosyal hizmet bağlamında Aliya'nın eserlerini ele alan bu çalışma, Aliya'nın eserlerinde çerçevesi özgürlük ve ahlakla çizilmiş bir perspektiften birey, aile ve toplum bütün yönleriyle ele alınmıştır. Sosyal hizmet alanları içinde yer alan çocuk, genç, kadın, yaşlı, suçlu bütün gruplar ayrı ayrı ele alınmış suç, intihar, alkolizm, ruhsal bunalımlar gibi toplumsal sorunların sosyoekonomik, kültürel ve siyasal sebepleri analiz edilmiştir.

Aliya'ya göre maddi ve manevi olarak iki yönü bulunan insan şimdiye kadar hep tek yönlü olarak ele alınmıştır. Bu durum insan adına yapılan çalışmalarda bile insanın bir yönünün hep eksik kalmasına neden olmuştur. Bu nedenle Aliya, insanı bir maddi ve manevi yönleriyle bir bütün olarak ele almıştır.

Aliya düşüncesinde sosyal hizmet alanları açısından kesişen noktalar daha net olarak şu şekilde ifade edilebilir: Sosyal hizmet toplum için bireyi feda etmez, Aliya İzzetbegoviç'in 
düşüncelerinin temelinde ve önceliğinde de insan vardır. Özgür tercihleriyle şahsiyet kazanmış fertlerin inşa ettiği bir ahlak sistemiyle örülmüş bir toplum ancak erdemli bireyi yeniden üretebilir. $\mathrm{Bu}$ yönüyle sosyal hizmetin merkezinde özne olan insan olduğu gibi Aliya'nın fikirlerinin merkezinde de önce insan olduğu görülmüştür.

Sosyal hizmetin temel alanları olan kadın, aile, yaşlı, çocuk, göçmen ve suçlularla ilgili Aliya'nın yapmış olduğu tespit ve analizler modern sosyal hizmet uygulamalarıyla örtüşmektedir. Bu doğrultuda Aliya düşüncesinde modern toplumlarda aile kurumunun zayıfladığı, kadın emeğinin ucuz iş gücü olarak kullanıldığı ve kadının ev içinde ki iktisadi değerinin tanınmadığı, çocuk ve yaşlıların pek çok dezavantajla karşı karşıya kaldıkları vurgulanmıştır.

Benzer şekilde Aliya düşüncesinde küresel sosyal hizmet boyutuyla insan hakları, sosyal adalet, özgürlük, eşitlik gibi kavramların değerlendirmeye alındığı görülmüştür. Bütün bu değerlere olan ihtiyacın sık sık vurgulandığı ve küresel sosyal hizmet çerçevesinde birer insanlık suçları olan ırkçılık, soykırım, savaş suçlarının da etraflıca analiz edildiği görülmüştür. Özellikle ırkçılık ve soykırım gibi suçların bir toplumu toptan karalamanın aracı olarak kullanılamayacağını vurgulaması ve suçun bireyselliğinin altını çizmesiyle de modern hukuk, insan hakları ve sosyal hizmet açısından evrensel bir tutum geliştirmesi de oldukça önemlidir.

Yaşadığı dönem ve coğrafya dikkate alındığında farklılıklara yer verilmeyen, öteki olana yaşam hakkı tanınmayan, özgür düşüncenin olmadığı, adaletin askıda olduğu ve her türlü insan hakları ihlalinin gerçekleştiğini anlıyoruz. Bütün bu olumsuz koşullara rağmen Aliya'nın verdiği mücadelenin ve ortaya koyduğu fikirlerin merkezinde insanın yer alması, onun özgürlük, eşitlik, demokrasi, ahlak ve insan haklarına olan inancını kaybetmediğini göstermesi bakımından oldukça önemlidir. Bu sonuç, Aliya'nın düşüncelerinin evrensel değerler ölçüsünde günümüzün sosyal sorunlarına ve sosyal hizmet alanları kapsamında değerlendirilen konularına açıklık getirmede dikkate alınması gerektiğini ortaya koymaktadır. Başka bir deyişle Aliya İzzetbegoviç’in eserlerinin çerçevesini oluşturan insan odaklılık, özgürlük, insan hakları ve adalet vurgusu modern sosyal hizmet paradigmasıyla örtüştüğü söylenebilir. Bu bağlamda Aliya düşüncesinin, sosyal hizmet gibi sosyal bilim alanları açısından yeniden ele alınmasının, insan odaklı çalışmalara sağlayacağı katkı bakımından faydalı olacağı düşünülmektedir.

\section{Kaynakça}

Akçay, M. (2016). Aliya İzzetbegoviç ve düşünce dünyası, [Yayımlanmamış yüksek lisans tezi] Atatürk Üniversitesi Sosyal Bilimler Enstitüsü.

Akın, M.H. \& Karaarslan, F. (2016). Çağdaş İslam Düşüncesinde Aliya İzzetbegoviç, Muhafazakar Düşünce Dergisi, 13(48): 41-58

Aydın, M. (2013). Aliya İzzetbegoviç’te Ütopya ve Dram, Merve Akkuş Güvendi (Ed.), Doğu Batı Arasında İslam Birliği İdeali Vefatının 10. Yılında Aliya İzzetbegoviç, 41-53

Ceylan, H. (2020). Sosyal Değerden Sosyal Soruna Yaşl11lk: Geleneksel Toplumdan Modern Topluma Değişen Yaşlı1ık Algısı. Harun Ceylan (Ed.), Modern Hayat ve Yaşlılık, Nobel Yayınları. s. $25-54$

Çil, A.(2018). Özgür ve Bilge Lider Aliya İzzetbegoviç, Timaş Yayınları.

Dilik, S. (1980). Sosyal Güvenlik ve Sosyal Hizmetler Arasındaki İlişkiler, Ankara Üniversitesi SBF Dergisi, 35(1). 73-84

$1-22$.

Duyan, V. (2003). Sosyal Hizmetin İşlev ve Rolleri, Toplum ve Sosyal Hizmet Dergisi, 14(2): 
Emgili, F. (2012). Bosna Hersek Trajedisinde (1992-1995) Türk Birliği. Sayı 21, s.65-66.

Gökbayrak, Ş. (2009). Refah Devletinin Dönüşümü ve Bakım Hizmetlerinin Görünmez Emekçileri Göçmen Kadınlar, Çalışma ve Toplum Dergisi,(2). 55-82.

Hacımeyliç, K. (2013). Aliya İzzetbegoviç'in Hayatı ve İslam Dünyasına Bakışı, erve Akkuş Güvendi), Doğu Batı Arasında İslam Birliği İdeali Vefatının 10. Yılında Aliya İzzetbegoviç, 15-19

İslam, C. (2013). “İzzetbegoviç’in “Ahlakı, Kaderi ve Teslimiyeti”, M.A.Güvendi (Ed.), Doğu Batı Arasında İslam Birliği İdeali,Vefatının 10. Yılında Aliya İzzetbegoviç, 73-83. Yayınları.

İzzetbegoviç, A.(2003). Tarihe tanıklı̆̆ım. (Çev. A. Erkilet, A. Demirhan. H. Öz) Klasik

İzzetbegoviç, A.(2007a). İslam deklarasyonu ve İslami yeniden doğuşun sorunları. (Çev. R .Ademi) İstanbul: Fide Yayınları.

İzzetbegoviç, A.(2007b). Köle olmayacă̆ız. K. Terzioğlu (Ed). İstanbul: Fide Yayınları.

İzzetbegoviç, A.(2011a). Özgürlüğe kaçışım-Zindandan notlar.(Çev. H.T. Başoğlu) . İstanbul: Klasik Yayınları.

İzzetbegoviç, A.(2011b). Konuşmalar. (Çev. F. Altun, R. Ahmetoğlu). Klasik Yayınları.

İzzetbegoviç, A.(2019). Doğu ve batı arasında İslam. (Çev. E. Nurikiç). Ketebe Yayınları.

Karaarslan, F. (2010). Entelektüel üzerine eleştirel bir çalışma: Aliya İzzetbegoviç örneği, [Yayımlanmamış yüksek lisans tezi]Selçuk Üniversitesi Sosyal Bilimler Enstitüsü. 111-128.

Karaarslan, F. (2012). Aliya İzzetbegoviç'in Ahlâk ve Siyaset Anlayışı, TYB Akademi, 2(4).

Karaarslan, F. (2013). Medeniyet Tartışmalarına Antiütopyacı Bir Yaklaşım: Aliyal̇zzetbegoviç Örneği, M.A.Güvendi (Ed.), Doğu Batı Arasında İslam Birliği İdeali,Vefatının 10. Yılında Aliya İzzetbegoviç, 25-33.

Özcan, M. (2017). Değişim ve süreklilik bakımından Balkan İslamı: Aliya İzzetbegoviç üzerine bir çalışma, [Yayımlanmamış doktora tezi]Çukurova Üniversitesi Sosyal Bilimler Enstitüsü,

Özdemir, M. (2014). Aliya İzzetbegoviç düşüncesinde üçüncü yol kavramı ve felsefi temelleri, [Yayımlanmamış yüksek lisans tezi]. Gazi Üniversitesi Sosyal Bilimler Enstitüsü.

Özdemir, S. (2005). Başlangıcından Günümüze Refah Devletlerinde Sosyal Harcamaların Analizi, Sosyal Siyaset Konferansları Dergisi, 50. 153-204.

Özyurt, C. (2016). İki Dünya Arasında İnsan: Aliya İzzetbegoviç'in Din Kuramı ve İslâm Yorumu, Hece Dergisi, 20(229), 219-252. $1142-1165$

Tek, S. (2019). Irkçılık karşıtı sosyal hizmet uygulaması. Toplum ve Sosyal Hizmet, 30(3),

Toktaş, F. (2016). Yenilikçi Müslüman Düşünür Olarak Aliya İzzetbegoviç, Dokuz Eylül Üniversitesi Illahiyat Fakültesi Dergisi, XLIV: 7-45.

Ulutaş, A.D.(2015). "Yok" Edilen İnsanlık; Soykırım Suçu ve Uluslararası Sosyal Hizmet, Celal Bayar Üniversitesi Sosyal Hizmet Sempozyumu, s. 181-188

www. hacettepe. edu.tr. (2014). Sosyal Hizmetin Küresel Tanım1, http://www.shy.hacettepe.edu.tr/tr/menu/genel_tanitim-10. Erişim Tarihi: 15.06.2020. 
www.ombudsman.gov.tr, Soykırım suçunun önlenmesine ve cezalandırılmasına dair sözleşme, https://www.ombudsman.gov.tr/contents/files/32702-Soykirim-SucununOnlenmesine-Ve-Cezalandirilmasina-Dair-Sozlesme.pdf Erişim Tarihi: 20.06.2020. 